Acta Universitatis Lodziensis

www.czasopisma.uni.lodz.pl/foe/

3(335) 2018

DOI: http://dx.doi.org/10.18778/0208-6018.335.08

\author{
Izabela Ewa Młynarzewska-Borowiec \\ Uniwersytet Technologiczno-Humanistyczny im. K. Pułaskiego w Radomiu, \\ Wydział Nauk Ekonomicznych i Prawnych, Katedra Biznesu i Finansów Międzynarodowych, \\ i.mlynarzewska@uthrad.pl
}

\title{
Łączna produktywność czynników produkcji (TFP) i jej zróżnicowanie w krajach Unii Europejskiej
}

Streszczenie: Łączna produktywność czynników produkcji (Total Factor Productivity - TFP) jest syntetycznym miernikiem efektywności procesu produkcyjnego w kraju, wynikającej z postępu technicznego. Celem artykułu jest oszacowanie (za pomocą metod ekonometrycznych) poziomu i dynamiki TFP w poszczególnych krajach Unii Europejskiej w latach 2000-2014 oraz wskazanie kierunku zmian jej zróżnicowania w analizowanej grupie krajów. W artykule podejmuje się także próbę odpowiedzi na pytanie, czy w krajach Unii Europejskiej możliwa jest konwergencja produktywności, mająca istotny wpływ na ich proces konwergencji realnej.

Słowa kluczowe: łączna produktywność czynników produkcji, konwergencja produktywności, Unia Europejska

JEL: C21, C23, O47, O52 


\section{Wprowadzenie}

Łączna produktywność czynników produkcji (Total Factor Productivity - TFP) obok akumulacji czynników produkcji (pracy, kapitału rzeczowego i ludzkiego) stanowi istotną determinantę wzrostu gospodarczego kraju. Liczne badania empiryczne związane z problematyką wzrostu gospodarczego (Klenow, RodriguezClare, 1997: 75-114; Easterly, Levine, 2000: 177-219; Helpman, 2010: 19-33; Hulten, Isaksson, 2007: 1-46) wskazują, że większość obserwowanego zróżnicowania PKB per capita krajów wynika właśnie z różnicy w TFP, określanej w literaturze jako wartość rezydualna lub tzw. reszta Solowa. Odzwierciedla ona zmiany efektywności procesów produkcyjnych dokonujących się pod wpływem szeroko rozumianego postępu technicznego.

TFP jako syntetyczny miernik wpływu wiedzy technicznej na tempo wzrostu gospodarczego jest jednak wielkością nieobserwowalną, którą można oszacować, wykorzystując dwie grupy metod. Pierwsza z nich to metody indeksowe, które polegają na budowie syntetycznych statystycznych indeksów całkowitej produktywności, jak na przykład indeks Laspayresa, Paaschego, Fishera, a także najczęściej wykorzystane obecnie indeksy Törnqvista i Malmquista (Świerczewska, 2007: 73-83; Kuosmanen, Sipiläinen, 2004: 1-42; Bjurek, 1996: 303-313). Druga grupa to metody polegające na wykorzystaniu funkcji produkcji i oszacowaniu jej parametrów. Wykorzystywaną funkcją może być funkcja Cobba-Douglasa lub funkcja produkcji CES. Jeśli funkcja ma postać dwuczynnikowej funkcji Cobba-Douglasa (w postaci potęgowej) z neutralnym postępem technologicznym w sensie Hicksa, to TFP odpowiada czynnikowi opisującemu technologię produkcji, a jej obliczenie wymaga oszacowania współczynników elastyczności produkcji względem poszczególnych jej czynników (pracy i kapitału). Można tu wyróżnić na przykład metodę T. Tokarskiego (2008) czy G. Ascariego i V. Di Cosmo (2004) (Dańska-Borsiak, 2011: 13-26).

Kraje Unii Europejskiej wykazują dość znaczne zróżnicowanie dochodu per capita, zwłaszcza między krajami byłej piętnastki i grupą tzw. nowych krajów członkowskich, a większość badań empirycznych wskazuje na istnienie między nimi także zjawiska konwergencji realnej (Schadler, Mody, Abiad, Leigh, 2006: 1-53; Halmai, Vásáry, 2010: 229-253; Tatomir, Alexe, 2011: 1-12; Grzelak, Kujaczyńska, 2013: 393-404; Rapacki, Próchniak, 2014: 87-122; Młynarzewska-Borowiec, 2016: 57-71). Ponadto zwolennicy koncepcji TFP podkreślają konieczność postrzegania procesu konwergencji realnej w kategoriach konwergencji produktywności (productivity convergence) (Hulten, 2000: 1-77; Caselli, Tenreyro, 2005: 1-60).

Celem artykułu jest analiza poziomu i dynamiki łącznej produktywności czynników produkcji w poszczególnych krajach Unii Europejskiej (z wyłączeniem Chorwacji), głównie w kontekście zmian zróżnicowania TFP w ana- 
lizowanej grupie krajów w latach 2000-2014. W części pierwszej scharakteryzowano metodologię oszacowania TFP, w drugiej zaś dobór materiału statystycznego. W części trzeciej ujęto wyniki badania mającego na celu wyznaczenie poziomu TFP w poszczególnych krajach członkowskich UE oraz - na ich podstawie - dokonano analizy zróżnicowania poziomu i dynamiki TFP w „starych” i „nowych” krajach Unii Europejskiej. Podjęto także wstępną próbę oceny, czy w Unii Europejskiej można mówić o istnieniu tzw. konwergencji produktywności. W niniejszym opracowaniu próbuje się zweryfikować hipotezę o istotnym zróżnicowaniu krajów UE w zakresie poziomu i dynamiki łącznej produktywności czynników produkcji, które może mieć wpływ na kształtowanie się procesu konwergencji realnej w Unii Europejskiej.

\section{Metodologia oszacowania TFP}

W niniejszym artykule punktem wyjścia do wyznaczenia poziomu TFP jest neoklasyczna dwuczynnikowa funkcja produkcji $Y=f(K, L)$, gdzie $Y$ oznacza wielkość produkcji, a $K$ i $L$ - odpowiednio - nakłady kapitału i pracy. Zakładając neutralny typ postępu technicznego w sensie Hicksa (nie zmienia się krańcowa stopa substytucji między pracą i kapitałem), funkcja produkcji może przyjąć postać funkcji Cobba-Douglasa:

$$
Y_{t}=A_{t} f\left(K_{t}, L_{t}\right),
$$

gdzie $A_{t}$ obrazuje technologię produkcji, która może być utożsamiana z łączną produktywnością czynników produkcji (TFP) w okresie $t$.

Wyznaczenie TFP wymaga przede wszystkim sprecyzowania postaci powyższej funkcji produkcji. Z reguły przyjmuje się jej następującą postać potęgową:

$$
Y_{t}=A_{t} K_{t}^{\alpha} L_{t}^{1-\alpha},
$$

gdzie $\alpha, 1-\alpha$ - elastyczność produkcji względem, odpowiednio, nakładów kapitału $K$ i nakładów pracy $L$.

W wyniku podzielenia obu stron równania (2) przez nakłady pracy $\left(L_{t}\right)$ funkcja przyjmuje postać:

$$
\left(\frac{Y_{t}}{L_{t}}\right)=A_{t}\left(\frac{K_{t}}{L_{t}}\right)^{\alpha},
$$

poziom TFP wynosi zatem: 


$$
A_{t}=T F P_{t}=\frac{\left(\frac{Y_{t}}{L_{t}}\right)}{\left(\frac{K_{t}}{L_{t}}\right)^{\alpha}},
$$

gdzie: $\left(\frac{Y_{t}}{L_{t}}\right)$ - wydajność (produktywność) pracy, a $\left(\frac{K_{t}}{L_{t}}\right)$ - techniczne uzbrojenie pracy.

Poziom łącznej produktywności czynników produkcji $A_{t}$ w równaniu (3) można opisać wyrażeniem $A_{0} e^{\text {gt }}>0$, gdzie $A_{0}$ oznacza łączną produktywność czynników produkcji w okresie $t=0$, a $g$ stopę postępu technicznego, będącą stopą wzrostu łącznej produktywności czynników produkcji.

Wobec powyższego równie (3) można zapisać jako:

$$
\left(\frac{Y_{t}}{L_{t}}\right)=A_{0} e^{g t}\left(\frac{K_{t}}{L_{t}}\right)^{\alpha}
$$

a następnie, po zlogarytmowaniu stronami, w zlinearyzowanej postaci:

$$
\ln \left(\frac{Y_{t}}{L_{t}}\right)=\ln A_{0}+g t+\alpha \ln \left(\frac{K_{t}}{L_{t}}\right) .
$$

W powyższym równaniu logarytm naturalny z łącznej produktywności czynników produkcji (TFP) określa wyrażenie $\ln A_{0}+g t$. Z równania (6) wynika, że poziom wydajności pracy jest rosnącą funkcją wyjściowego poziomu łącznej produktywności czynników produkcji, stopy postępu technicznego i technicznego uzbrojenia pracy.

W empirycznym badaniu mającym na celu wyznaczenie poziomu TFP w poszczególnych krajach Unii Europejskiej w latach 2000-2014 wykorzystano metodę Tokarskiego (2008: 38-53), polegającą na szacowaniu parametrów strukturalnych modelu ekonometrycznego zbudowanego na bazie powyższego równania wydajności (6).

W wyjściowym punkcie badania przejęto następującą postać modelu:

$$
\ln \left(\frac{Y_{i t}}{L_{i t}}\right)=\ln A_{0}+g t+\alpha \ln \left(\frac{K_{i t}}{L_{i t}}\right)+\varepsilon_{i t},
$$

gdzie: $Y_{i t}$ - PKB kraju $i$ w okresie $t \mathrm{w}$ mln USD, $L_{i t}$ - zasoby pracy, liczba pracujących w mln osób kraju $i$ w okresie $t, K_{i t}$ - zasoby kapitału rzeczowego w mln USD kraju $i$ w okresie $t, t$-zmienna czasowa, $g$ - stopa postępu technicznego 
w sensie Hicksa (stopa wzrostu TFP), $\alpha$ - elastyczność PKB względem nakładów kapitału $K, 1-\alpha$ - elastyczność PKB względem nakładów pracy $L$.

Jednak szacując model w powyższej postaci, zakłada się, że wyrażenie $\ln A_{0}+g t$ (a zatem poziom TFP) jest takie samo dla wszystkich analizowanych krajów. Byłoby to znaczne uproszczenie. W modelu takim nie uwzględnia się bowiem efektu indywidualnego poszczególnych krajów (ten sam wyraz wolny $\ln A_{0}$ dla każdej jednostki panelu). Wobec powyższego wskazane wydaje się przeprowadzenie procedury dywersyfikacji wyrazu wolnego przez potraktowanie modelu (7) jako modelu z efektami indywidualnymi (fixed effect). Zmodyfikowany model przyjmuje zatem następującą postać:

$$
\ln \left(\frac{Y_{i t}}{L_{i t}}\right)=\ln A_{0}+\sum_{j=1}^{26} \ln \left(A_{j}\right) w_{j}+g t+\alpha \ln \left(\frac{K_{i t}}{L_{i t}}\right)+\varepsilon_{i t},
$$

W powyższym modelu parametr $\ln A_{0}$ nie stanowi już wspólnego wyrazu wolnego dla wszystkich jednostek panelu (w tym przypadku krajów), a stałą dla wybranego kraju bazowego (w tym przypadku Luksemburga - o najwyższym poziomie wydajności pracy i technicznego uzbrojenia pracy). Zmienna $w_{j}$ jest zmienną zero-jedynkową dla pozostałych 26 krajów, a stojący przy niej parametr strukturalny $\ln \left(A_{j}\right)$ interpretowany jest jako odchylenie od stałej w kraju bazowym. Tym samym wyrażenie $\ln A_{0}+\ln A_{j}$ jest stałym w czasie wyrazem wolnym dla kraju $j$.

Po oszacowaniu parametrów strukturalnych modelu (8), w tym kluczowego z punktu widzenia przeprowadzanego badania parametru $\alpha$ (elastyczności wydajności pracy względem technicznego uzbrojenia pracy), bazując na równaniu (4), wyliczono poziomy TFP dla krajów Unii Europejskiej w poszczególnych latach analizowanego okresu za pomocą następującej formuły:

$$
\operatorname{TFP}_{i t}=\frac{\left(\frac{Y_{i t}}{L_{i t}}\right)}{\left(\frac{K_{i t}}{L_{i t}}\right)^{a}},
$$

gdzie: $T F P$ - TFP kraju $i$ w okresie $t, a$ - oszacowana wartość parametru strukturalnego $\alpha$.

\section{Dobór materiału statystycznego}

Wartości PKB (zmienna $Y_{i t}$ ) z lat 2000-2014 poszczególnych krajów Unii Europejskiej, liczone według parytetu siły nabywczej (ceny stałe 2011), wyrażone w dolarze międzynarodowym (Geary-Khamis dollar), uzyskano z bazy danych Banku 
Światowego (WDI database). Z kolei dane dotyczące liczby pracujących (zmienna $\left.L_{i t}\right) \mathrm{w}$ analizowanym okresie uzyskano z bazy danych Międzynarodowej Organizacji Pracy (ILOSTAT database).

$\mathrm{Z}$ uwagi na fakt, iż w żadnej bazie danych makroekonomicznych nie znaleziono danych dotyczących zasobów kapitału rzeczowego (zmienna $K_{i f}$ ) dla krajów członkowskich Unii Europejskiej, wartość tych zasobów oszacowano według procedury opracowanej przez K. Mroczek i T. Tokarskiego (2014). Dla każdego $\mathrm{z}$ analizowanych krajów przyrost zasobów kapitałowych można zapisać jako:

$$
\Delta K_{t}=I_{t}-\delta \mathrm{K}_{t-1},
$$

gdzie: $K_{t}$ - zasób kapitału w roku $t, I_{t}$ - strumień inwestycji, $\delta \in(0,1)$ - stopa deprecjacji kapitału rzeczowego, przyjmowana zwyczajowo na poziomie $5 \%$.

Przyjmując, że $\Delta K_{t}=K_{t}-K_{t-1}$, poziom zasobu kapitału w kraju w roku $t$ wynosi:

$$
K_{t}=I_{t}+(1-\delta) \mathrm{K}_{\mathrm{t}-1} .
$$

Uogólniając, prowadzi to do zależności:

$$
K_{t}=\sum_{\tau=0}^{\infty}(1-\delta)^{\tau} I_{t-\tau}
$$

Ponieważ wyrażenie $(1-\delta)^{\tau}$ jest malejącym ciągiem geometrycznym, a $I_{t}>I_{t-1}$, wyrażenie $(1-\delta)^{\tau} I_{t-\tau}$ jest zatem również malejącym ciągiem geometrycznym, co pozwala założyć, iż:

$$
K_{t}=\sum_{\tau=0}^{\infty}(1-\delta)^{\tau} I_{t-\tau} \approx \sum_{\tau=0}^{n}(1-\delta)^{\tau} I_{t-\tau}
$$

Uwzględnienie dłuższego horyzontu czasowego skumulowania inwestycji (większa wartość $n$ ) daje możliwość uzyskania bardziej dokładnego przybliżenia całkowitego zasobu kapitału w okresie $t$. Policzone szacunki zasobów kapitału rzeczowego są zatem jedynie przybliżoną wartością zmiennej $K_{i t}$. Przybliżenia te uwzględniają jednak zasoby kapitału rzeczowego powstałe na skutek inwestycji realizowanych w ciągu ostatnich dziesięciu lat. Generalnie rzecz biorąc, opisują one zatem względnie najnowocześniejsze i najbardziej produktywne zasoby kapitałowe.

Ze względu na fakt, iż z bazy danych Banku Światowego (WDI database) uzyskano dane dotyczące strumieni inwestycji (gross fixed capital formation) $I_{t}$ (USD, ceny stałe 2011) dla tzw. nowych krajów UE jedynie za lata 1991-2014 oraz do- 
datkowo kierując się koniecznością uwzględnienia dość długiego horyzontu czasowego $(n=9)$, możliwe było oszacowanie wartości całkowitych zasobów kapitału rzeczowego w 27 krajach UE („nowych” i „starych”) dla lat 2000-2014. Stopę deprecjacji kapitału $\delta$ przyjęto na poziomie $5 \%$.

Otrzymane w wyniku powyższej procedury wartości kapitału rzeczowego podzielono przez liczbę pracujących, otrzymując wartość technicznego uzbrojenia pracy w poszczególnych krajach w analizowanym okresie $\left(K_{i t} / L_{i i}\right)$. Obliczono także poziomy wydajności pracy w poszczególnych krajach UE, mierzone jako PKB na jednego pracującego $\left(Y_{i t} / L_{i t}\right)$. Tak przygotowane dane wykorzystano następnie jako zmienne w modelu (8).

\section{Zróżnicowanie krajów UE w zakresie poziomu i dynamiki TFP w świetle otrzymanych wyników}

Wyniki oszacowania parametrów strukturalnych modelu (8) zawiera tabela 1. Ze względu na fakt, że techniczne uzbrojenie pracy jest zmienną endogeniczną, czyli zależy od tego samego składnika zakłócającego co zmienna objaśniana w modelu, czyli PKB na pracującego, MNK staje się obciążonym estymatorem parametrów strukturalnych modelu. Dlatego do oszacowania modelu wykorzystano estymator Uogólnionej Metody Momentów (UMM), jako instrumenty wykorzystując stałą $\left(\ln A_{0}\right)$, zmienną czasową $(t)$, opóźnione o jeden okres zmienne $\ln \left(K_{i t} / L_{i t}\right), \ln \left(Y_{i t} / L_{i t}\right)$ oraz zmienne binarne.

Tabela 1. Wyniki estymacji modelu (8); estymator UMM

\begin{tabular}{|l|c|c|c|c|}
\hline \multicolumn{1}{|c|}{ Zmienna } & Wspólczynnik & Błąd stand. & $\boldsymbol{z}$ & Wartość $\boldsymbol{p}$ \\
\hline $\ln A_{0}$ & $9,00543^{*}$ & 0,36548 & 24,6400 & $<0,00001$ \\
\hline Belgia & $-0,573675^{*}$ & 0,023801 & $-24,1030$ & $<0,00001$ \\
\hline Dania & $-0,726225^{*}$ & 0,0227079 & $-31,9811$ & $<0,00001$ \\
\hline Niemcy & $-0,674425^{*}$ & 0,0315977 & $-21,3441$ & $<0,00001$ \\
\hline Irlandia & $-0,555559^{*}$ & 0,024555 & $-22,6251$ & $<0,00001$ \\
\hline Grecja & $-0,742783^{*}$ & 0,0522536 & $-14,2150$ & $<0,00001$ \\
\hline Hiszpania & $-0,780322^{*}$ & 0,0380208 & $-20,5236$ & $<0,00001$ \\
\hline Francja & $-0,669783^{*}$ & 0,0269724 & $-24,8322$ & $<0,00001$ \\
\hline Włochy & $-0,58917^{*}$ & 0,0311874 & $-18,8913$ & $<0,00001$ \\
\hline Holandia & $-0,61524^{*}$ & 0,0271364 & $-22,6722$ & $<0,00001$ \\
\hline Austria & $-0,656208^{*}$ & 0,0240053 & $-27,3359$ & $<0,00001$ \\
\hline Portugalia & $-0,974164^{*}$ & 0,0471147 & $-20,6764$ & $<0,00001$ \\
\hline Finlandia & $-0,726207^{*}$ & 0,0265421 & $-27,3606$ & $<0,00001$ \\
\hline Szwecja & $-0,696651^{*}$ & 0,0247708 & $-28,1239$ & $<0,00001$ \\
\hline
\end{tabular}




\begin{tabular}{|l|c|c|c|c|}
\hline \multicolumn{1}{|c|}{ Zmienna } & Wspólczynnik & Błąd stand. & $\boldsymbol{z}$ & Wartość $\boldsymbol{p}$ \\
\hline W. Brytania & $-0,668788^{*}$ & 0,0341778 & $-19,5679$ & $<0,00001$ \\
\hline Bułgaria & $-1,16625^{*}$ & 0,0904896 & $-12,8882$ & $<0,00001$ \\
\hline Czechy & $-0,88724^{*}$ & 0,050873 & $-17,4403$ & $<0,00001$ \\
\hline Estonia & $-1,08945^{*}$ & 0,0604491 & $-18,0227$ & $<0,00001$ \\
\hline Cypr & $-1,02157^{*}$ & 0,0530811 & $-19,2455$ & $<0,00001$ \\
\hline Łotwa & $-1,18848^{*}$ & 0,0684097 & $-17,3730$ & $<0,00001$ \\
\hline Litwa & $-1,00228^{*}$ & 0,0753243 & $-13,3062$ & $<0,00001$ \\
\hline Węgry & $-0,890362^{*}$ & 0,0591999 & $-15,0399$ & $<0,00001$ \\
\hline Malta & $-0,725612^{*}$ & 0,0508287 & $-14,2756$ & $<0,00001$ \\
\hline Polska & $-0,998423^{*}$ & 0,075998 & $-13,1375$ & $<0,00001$ \\
\hline Rumunia & $-1,1226^{*}$ & 0,0551835 & $-20,3431$ & $<0,00001$ \\
\hline Słowenia & $-0,893514^{*}$ & 0,0439902 & $-20,3117$ & $<0,00001$ \\
\hline Słowacja & $-0,987936^{*}$ & 0,0720908 & $-13,7040$ & $<0,00001$ \\
\hline ln $\left(K_{i t} / L_{i j}\right)$ & $0,230464^{*}$ & 0,030666 & 7,5153 & $<0,00001$ \\
\hline$t$ & $0,0201368^{*}$ & 0,0020362 & 9,8894 & $<0,00001$ \\
\hline $\begin{array}{l}\text { Kryterium UMM: } \\
\text { test J }\end{array}$ & \multicolumn{5}{|c|}{2,4058} \\
\hline $\begin{array}{l}\text { L. obserwacji } \\
\text { L. instrumentów }\end{array}$ & \multicolumn{5}{|c|}{$378,120886]$} & \\
\hline
\end{tabular}

* Istotność na poziomie 1\%; wyniki otrzymane w drugim kroku estymacji; test J (Sargana) weryfikuje zasadność wykorzystania wybranych instrumentów w metodzie UMM (w nawiasie kwadratowym podano wartość p testu)

\section{Źródło: obliczenie własne w programie GRETL}

Oszacowane wartości odchyleń od stałej dla poszczególnych krajów $\ln \left(A_{j}\right)$ są ujemne, istotne statystycznie i dość zróżnicowane. Oznacza to, że poziom TFP w poszczególnych krajach UE był niższy od jej poziomu dla Luksemburga (kraju bazowego). Zróżnicowanie wspomnianych współczynników pozwala przypuszczać, że poziom TFP w analizowanej grupie krajów różnił się i był najniższy w Bułgarii, Rumunii, Portugalii, na Łotwie, w Estonii i na Cyprze. W świetle otrzymanych wyników średnie tempo postępu technicznego (średnia stopa wzrostu łącznej produktywności czynników produkcji) w analizowanej grupie krajów kształtowała się na poziomie około $2 \%$.

W świetle wyników oszacowań równania (8) elastyczność wydajności pracy względem technicznego uzbrojenia pracy ( $a$, czyli oszacowana wartość parametru strukturalnego $\alpha$ przy zmiennej $K_{i l} / L_{i l}$ ) wynosiła $0,230464 \mathrm{i}$ była istotna statystycznie. Oszacowaną wartość $a$ i formułę (9) wykorzystano następnie do policzenia poziomu łącznej produktywności czynników produkcji (TFP) w poszczególnych 27 krajach UE w latach 2000-2014.

Łączna produktywność czynników wytwórczych (TFP) w poszczególnych krajach członkowskich, tak jak już wstępnie sugerowano, analizując oszacowania parametrów strukturalnych modelu (8), okazała się znacznie zróżnicowana (zob. rys. 1). 


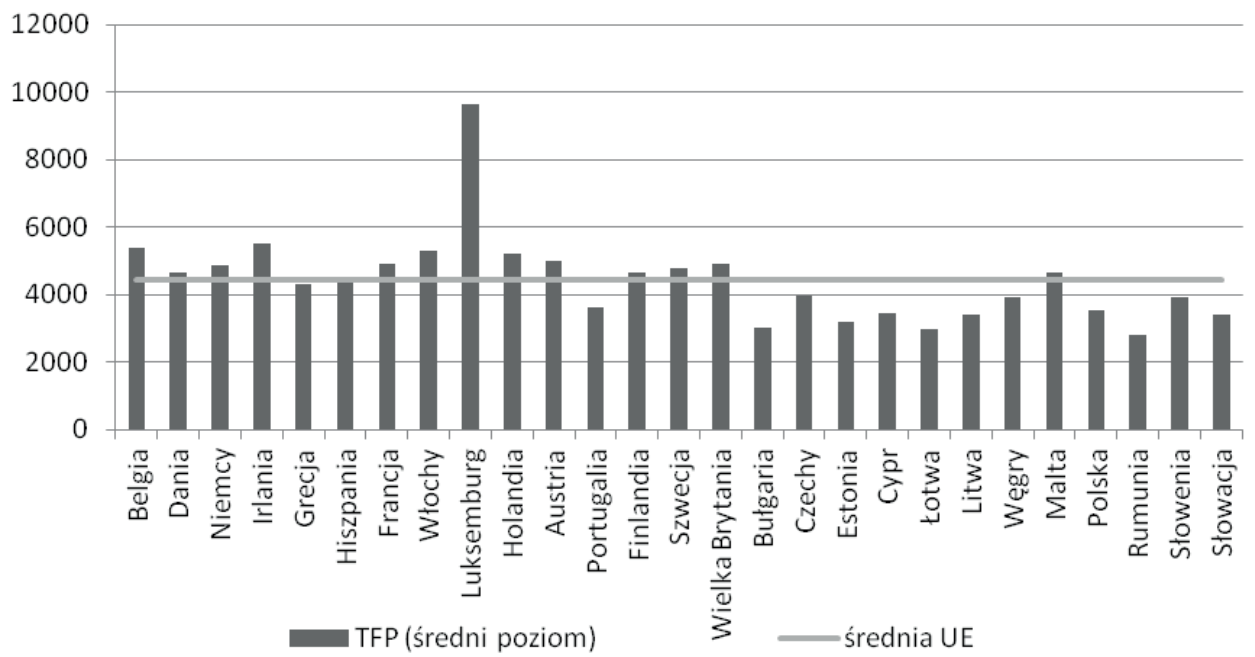

Rysunek 1. Średni poziom TFP w poszczególnych krajach UE w latach 2000-2014

Źródło: opracowanie własne

Tabela 2. Średni poziom TFP w krajach UE w latach 2000-2014

\begin{tabular}{|c|c|c|c|c|c|c|c|c|}
\hline Grupa krajów & 2000 & 2001 & 2002 & 2003 & 2004 & 2005 & 2006 & 2007 \\
\hline UE-27 & 3594,3 & 3741,2 & 3905,2 & 3970,6 & 4108,0 & 4215,2 & 4512,1 & 4692,7 \\
\hline UE-15 & 4366,5 & 4528,6 & 4679,3 & 4709,8 & 4847,0 & 4918,0 & 5262,2 & 5429,7 \\
\hline UE-12 & 2629,1 & 2756,9 & 2937,6 & 3046,7 & 3184,3 & 3336,9 & 3574,4 & 3771,6 \\
\hline Grupa krajów & 2008 & 2009 & 2010 & 2011 & 2012 & 2013 & 2014 & \\
\hline UE-27 & 4778,9 & 4563,9 & 4657,7 & 4817,6 & 4812,2 & 4865,7 & 4978,8 & \\
\hline UE-15 & 5481,7 & 5249,4 & 5358,0 & 5512,7 & 5482,3 & 5531,4 & 5666,3 & \\
\hline UE-12 & 3900,3 & 3707,0 & 3782,3 & 3948,8 & 3974,5 & 4033,5 & 4119,5 & \\
\hline
\end{tabular}

Źródło: obliczenia własne

Biorąc pod uwagę średni poziom łącznej produktywności czynników produkcji poszczególnych krajów UE w całym analizowanym okresie, najwyższym jej poziomem, powyżej średniej unijnej, wyróżniały się tzw. stare kraje UE: Belgia, Dania, Niemcy, Irlandia, Francja, Włochy, Luksemburg, Holandia, Austria, Finlandia, Szwecja i Wielka Brytania, a z grupy „,nowych” krajów członkowskich tylko Malta. Najniższy średni poziom TFP występował w Portugalii, Bułgarii, Estonii, Rumunii, na Łotwie i Cyprze. Generalnie rzecz biorąc, relatywnie wyższym poziomem TFP charakteryzowały się kraje grupy UE-15 (Austria, Dania, Szwecja, Finlandia, Niemcy, Portugalia, Hiszpania, Włochy, Grecja, Belgia, Holandia, Luksemburg, Irlandia, Wielka Brytania, Francja), niższym zaś grupy UE-12 (Czechy, Estonia, Malta, Cypr, Litwa, Łotwa, Polska, Węgry, Słowacja, Słowenia, Bułgaria, Rumunia).

Potwierdza to chociażby analiza średniego poziom TFP we wspomnianych dwóch grupach krajów w latach 2000-2014 (zob. tab. 2). 
W 2000 roku średni poziom TFP w krajach grupy UE-12 stanowił 60,2\% jej średniego poziomu w krajach „byłej” piętnastki i 73,1\% w Unii jako całości. W miarę upływu czasu dysproporcja ta jednak malała i w 2014 roku wynosiła odpowiednio $72,7 \%$ i $82,7 \%$.

W zakresie dynamiki TFP do 2005 roku ,nowe” kraje członkowskie utrzymywały dość wysoką, około dwu-trzypunktową przewagę nad krajami byłej ,piętnastki”. W ostatniej dekadzie przewaga ta wyraźnie zmniejszyła się. W 2006, 2010 i 2013 roku wynosiła zaledwie około 0,5 punktu procentowego.

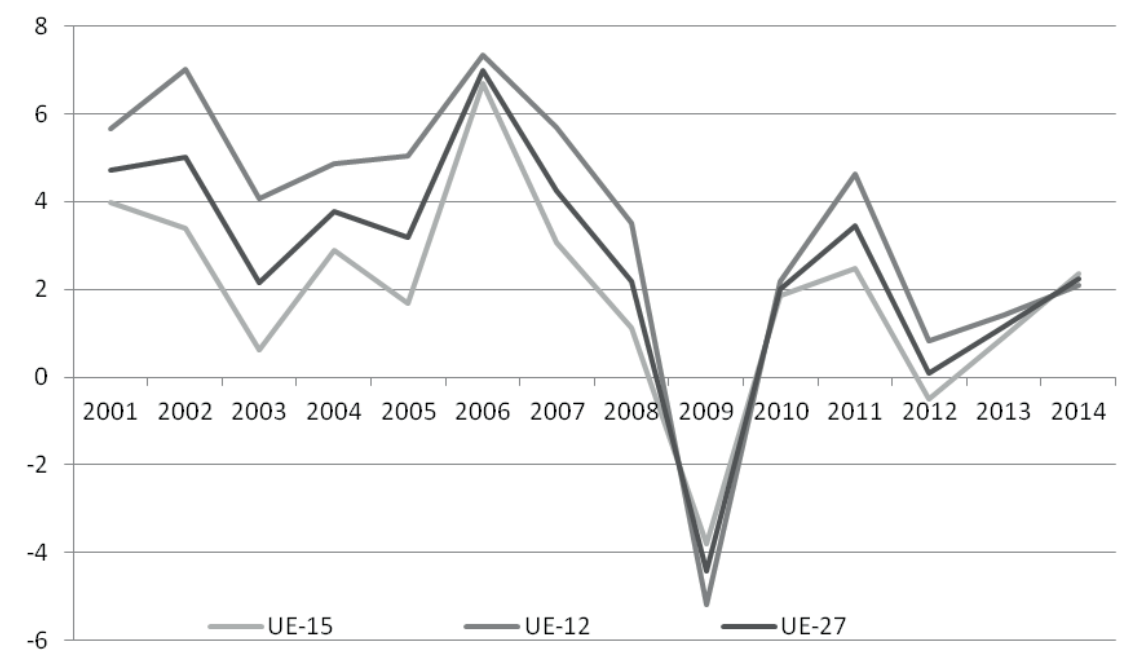

Rysunek 2. Dynamika TFP w krajach członkowskich UE w latach 2000-2014 [\%]

Źródło: opracowanie własne

Warto jednak dodać, że kraje UE-15 w 2009 roku doświadczyły znacznie niższego, w porównaniu z grupą UE-12, spadku TFP. W roku 2009 w większości krajów UE-12 odnotowano bowiem wyraźny spadek TFP (w tym najwyższy około piętnastoprocentowy na Litwie, Łotwie i w Estonii). Wyjątek stanowiły Polska i Malta, które utrzymały wzrost TFP na poziomie - odpowiednio - 2,8\% i $0,6 \%$. Z kolei w 2014 roku to kraje UE-15 charakteryzowały się niewielką przewagą (o 0,2 punktu procentowego) nad grupą UE-12 w zakresie wzrostu łącznej produktywności czynników produkcji.

Średniorocznie wyższe tempo wzrostu TFP w latach 2001-2014 wykazywały jednak „nowe” kraje UE, bo około 3,5\%, w tym głównie Rumunia (6,1\%), Litwa $(5,2 \%)$, Słowacja $(4,8 \%)$, Estonia $(4,4 \%)$ oraz Polska $(3,8 \%)$. Pozostałe kraje tej grupy wykazywały wzrost TFP na poziomie $2-3 \%$ rocznie. Wyjątek stanowił Cypr ze wzrostem produktywności na poziomie $1,2 \%$ rocznie i w zasadzie permanentnym spadkiem jej poziomu w ciągu ostatnich sześciu lat.

W krajach „byłej piętnastki” średnioroczne tempo wzrostu TFP było niższe i wynosiło $1,9 \%$, w tym najwyższe było w Niemczech $(3,1 \%)$, Portugalii $(2,6 \%)$ 
oraz Danii i Luksemburgu (2,3\%). Pozostałe kraje tej grupy wyróżniały się wzrostem TFP na poziomie oscylującym w okolicach średniej dla tej grupy, za wyjątkiem Grecji, Hiszpanii i Włoch ze wzrostem TFP na poziomie $0,9-1,2 \%$.

Generalnie rzecz biorąc, kraje UE wykazujące dość niski poziom TFP na początku badanego okresu wyróżniały się relatywnie wysoką, pozytywną jej dynamiką w całym analizowanym okresie. Można zatem przypuszczać, że w Unii Europejskiej zachodzi proces stopniowego „doganiania” krajów o najwyższym poziomie produktywności przez kraje relatywnie słabsze w tym zakresie, a TFP w poszczególnych krajach członkowskich Unii wykazuje tendencję do wyrównywania się. Słuszne wydaje się zatem postawienie hipotezy o istnieniu konwergencji produktywności (productivity convergence) w obrębie krajów Unii Europejskiej.

Wstępnie potwierdza ją badanie konwergencji absolutnej TFP dla krajów UE przeprowadzone z wykorzystaniem danych przekrojowych. W badaniu zastosowano następujące równanie regresji (14), na podstawie którego określono zależność między początkowym poziomem TFP (w roku 2000 jako bazowym) oraz przeciętnym tempem wzrostu łącznej produktywności w latach 2000-2014 w analizowanej grupie krajów:

$$
\frac{1}{T}\left[\ln \left(\frac{T F P_{i, 2004}}{T F P_{i, 2000}}\right)\right]=\vartheta+\theta \ln \left(T F P_{i, 2000}\right)+\mu_{i} .
$$

Wyniki oszacowania przeprowadzonego za pomocą KMNK ujęto w postaci graficznej na rysunku 3.

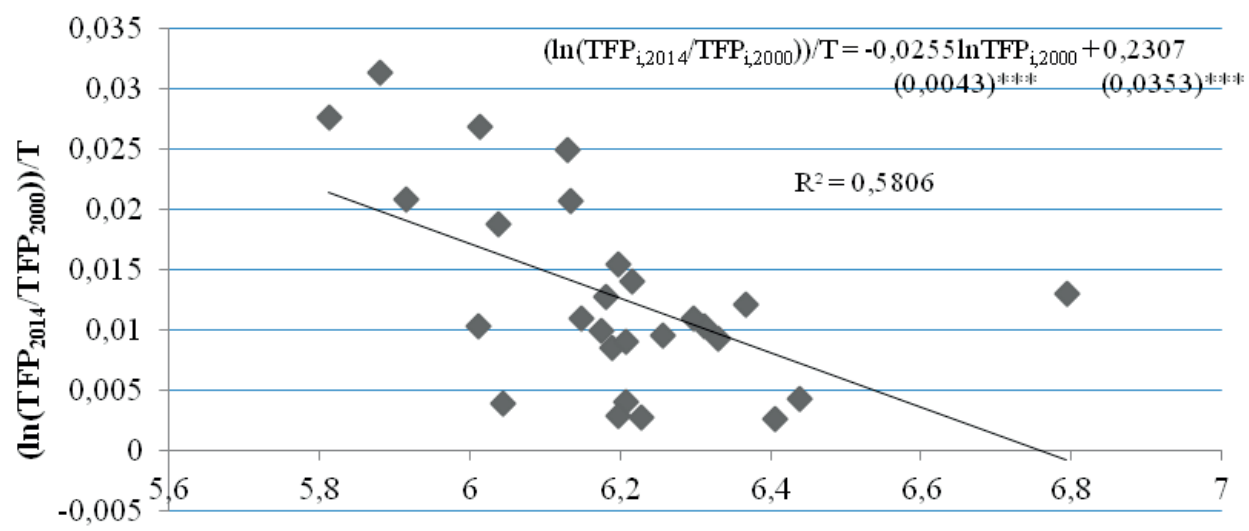

$\ln \left(\mathrm{TFP}_{2000}\right)$

Rysunek 3. Zależność między początkowym poziomem TFP (2000 r.) i tempem wzrostu TFP krajów UE w latach 2000-2014

Źródło: opracowanie własne 
Oszacowanie parametrów strukturalnych równania konwergencji wskazuje na występowanie statystycznie istotnej ujemnej zależności między początkowym poziomem TFP w krajach UE, tj. w 2000 roku, a tempem jej wzrostu w okresie 2000-2014 (oszacowana wartość parametru $\theta$ wynosi -0,026). Oczywiście powyższe badanie należy traktować jako wstępne. Weryfikacja postawionej hipotezy wymagałaby przeprowadzenia znacznie dokładniejszych badań i analiz.

\section{Podsumowanie}

Wyniki przeprowadzonego badania empirycznego wskazują na istotne zróżnicowanie krajów członkowskich Unii Europejskiej w zakresie poziomu i dynamiki TFP w latach 2000-2014. Kraje wykazujące wysoki poziom produktywności, do których niewątpliwie można zaliczyć kraje najdłużej funkcjonujące w ramach Wspólnoty (UE-15), charakteryzują się niższą jej dynamiką. Z odwrotną sytuacją mamy do czynienia w krajach przyjętych do Unii po 2004 roku. Kraje grupy UE-12 przy niskim wyjściowym poziomie TFP (w 2000 r.) wyróżniały się jej relatywnie wysokim wzrostem $\mathrm{w}$ analizowanym okresie. Stopień zróżnicowania krajów UE w zakresie łącznej produktywności wydaje się stopniowo zmniejszać. W przeprowadzonym badaniu wstępnie potwierdzono możliwość istnienia konwergencji produktywności (productivity convergence) w obrębie 27 krajów członkowskich. Stwierdzenie, czy faktycznie ona występuje i czy może rzutować na proces konwergencji realnej (stopniowe zbliżanie się krajów pod względem dochodów per capita), wymaga jednak dodatkowych testów i analiz empirycznych, między innymi rozszerzenia równania konwergencji absolutnej i testowania konwergencji warunkowej. Poza tym dokładniejsza analiza problemu wymagałaby zastosowania bardziej precyzyjnych metod badawczych, skonstruowania dynamicznych modeli panelowych czy zastosowania testów pierwiastka jednostkowego dla danych panelowych. Wspomniane analizy mogą stanowić obszar kolejnych badań ujętych w innym opracowaniu.

\section{Bibliografia}

Ascari G., Di Cosmo V. (2004), Determinants of Total Factor Productivity in the Italian Regions, „University of Pavia Working Paper”, nr 170, s. 1-27.

Bjurek H. (1996), The Malmquist Total Factor Productivity Index, ,Scandinavian Journal of Economics", t. 98, nr 2, s. 303-313, https://doi.org/10.2307/3440861.

Caselli F., Tenreyro S. (2005), Is Poland the Next Spain?, „NBER Working Paper”, nr 11045, s. 1-60, https://doi.org/10.2139/ssrn.649803.

Dańska-Borsiak (2011), Zróżnicowanie łącznej produktywności czynników produkcji według województw, „Wiadomości Statystyczne”, nr 12(607), s. 13-26. 
Easterly W., Levine R. (2000), It's Not Factor Accumulation: Stylized Facts and Growth Models, „The World Bank Economic Review”, t. 15, nr 2, s. 177-219, https://doi.org/10.2139/ ssrn.269108.

Grzelak A., Kujaczyńska M. (2013), Real convergence of the European Union members states - evaluation attempt, ,Management”, t. 17, nr 1, s. 393-404.

Halmai P., Vásáry V. (2010), Real convergence in the new Member States of the European Union (Shorter and longer term prospects), „European Journal of Comparative Economics”, t. 7, nr 1, s. 229-253.

Helpman E. (2010), The Mystery of Economic Growth, Belknap Press of Harvard University Press, Cambridge.

Hulten C. (2000), Total Factor Productivity: A Short Biography, „NBER Working Paper”, nr 7471, s. 1-77, https://doi.org/10.3386/w7471.

Hulten C.R., Isaksson A. (2007), Why Development Levels Differ: The Sources of Differential Economic Growth in a Panel of High and Low Income Countries, „NBER Working Paper”, nr 13469, s. 1-46, https://doi.org/10.3386/w13469.

Klenow P., Rodriguez-Clare A. (1997), The Neoclassical Revival in Growth Economics: Has It Gone Too Far?, „NBER Macroeconomics Annual 1997”, t. 12, s. 75-114, https://doi. org/10.2307/3585220.

Kuosmanen T., Sipiläinen T. (2004), On the Anatomy of Productivity Growth: A Decomposition of the Fisher Ideal TFP Index, „MTT Economic Research”, Discussion Papers nr 17, s. 1-42.

Młynarzewska-Borowiec I. (2016), Integration processes and marginal vertical $\beta$-convergence in the European Union Member States, „Central European Review of Economic \& Finance”, t. 11 , nr 1, s. 57-71.

Mroczek K., Tokarski T. (2014), Efekt grawitacyjny i techniczne uzbrojenie pracy a zróżnicowanie wydajności pracy w krajach UE, ,Studia Prawno-Ekonomiczne”, nr XCIII(93), s. 245-259.

Rapacki R., Próchniak M. (2014), Wpływ członkostwa w Unii Europejskiej na wzrost gospodarczy i realną konwergencję krajów Europy Środkowo-Wschodniej, „Ekonomia”, nr 39, s. 87-122.

Schadler S., Mody A., Abiad A., Leigh D. (2006), Growth in the Central and Eastern European Countries of the European Union, „IMF Occasional Papers”, nr 252, s. 1-53, https://doi. org/10.5089/9781589065543.084.

Świerczewska I. (2007), Total factor productivity. The embodied capital of knowledge, [w:] W. Welfe (ed.), Knowledge based economies. Models and methods, Peter Lang, Frankfurt.

Tatomir C.F., Alexe I., Laggards or performers? CEE vs. PIIGS countries' catch-up with the Euro area in the last ten years, „MPRA Paper”, nr 35715, s. 1-12.

Tokarski T. (2008), Oszacowanie regionalnych funkcji produkcji, „Wiadomości Statystyczne”, nr 10, s. $38-53$. 
Total Factor Productivity (TFP) and its Differentiation in the European Union Member States

\begin{abstract}
Total Factor Productivity (TFP) is the synthetic measure of effectiveness of the production process in a country due to technological progress. The aim of the article is to examine (with the use of econometric methods) the level and dynamics of TFP in the particular European Union member states in the period 2000-2014 and to point out the direction of TFP changes in the analysed group of countries. In the article one makes the attempt to answer the question whether the productivity convergence, influencing relevantly the real convergence process in the EU, is also possible.
\end{abstract}

Keywords: Total Factor Productivity, productivity convergence, the European Union JEL: C21, C23, O47, O52

\begin{tabular}{|l|l|}
\hline OPEN ACCESS & $\begin{array}{l}\text { C) by the author, licensee Łódź University - Łódź University Press, Łódź, Poland. } \\
\text { This article is an open access article distributed under the terms and conditions } \\
\text { of the Creative Commons Attribution license CC-BY } \\
\text { (http: //creativecommons.org/licenses/by/3.0/) }\end{array}$ \\
\cline { 2 - 2 } \\
Received: 2017-07-21; verified: 2017-11-06. Accepted: 2018-02-08
\end{tabular}

